IJIET, e-ISSN 2548-8430, p-ISSN 2548-8422, Vol. 1, No. 1, January 2017

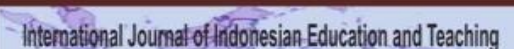

IJIET

International Journal of Indonesian Education and Teaching http://e-journal.usd.ac.id/index.php/IJIET

Sanata Dharma University, Yogyakarta, Indonesia

\title{
INVESTIGATING NON-ENGLISH DEPARTMENT STUDENTS' MOTIVATION IN EFL WRITING
}

\author{
Masyhudi Lathif \\ Language Training Centre \\ Muhammadiyah University of Yogyakarta \\ masyhudilathif@gmail.com \\ https://doi.org/10.24071/ijiet.v1i1.324
}

\begin{abstract}
This research explores students' voices towards motivation in English writing. It particularly scrutinizes the factors influencing students' motivation in the teaching and learning process of writing. The participants of this study were 20 non- English department students enrolled in English IV subject which was a general English course offered by Language Training Centre of Muhammadiyah University of Yogyakarta. The data were collected through a questionnaire with open-ended questions in which the participants were asked to write their opinion and reflection with regard to the issue. The results of this study revealed that there were six factors fostering learners' motivation in EFL writing class. These factors were institutional demands, linguistic needs, enthusiastic and inspiring teachers, engaging activities and tasks, interesting topics, and positive learning atmosphere. The present study suggested that there should be a collaborative negotiation between the teacher and students to create an enjoyable learning atmosphere. This also necessitated teachers to examine learners' needs, institutional expectations, aswell as their characteristics and voices in EFL writing.
\end{abstract}

Keywords: motivation, non-English department students, EFL writing

\section{Introduction}

Motivation has long been regarded as one of the primary factors in determining one's success in second and foreign language learning. To verify this view, a large body of literature has attempted to discover the role of motivation in fostering language learning process (see, for example, Dornyei, 1994; Ellis, 1994; Oxford \& Shearin, 1996; Gass \& Selinker, 2001). Dornyei (1994) asserts that motivation has become one of the principal determinants in learners' achievement in L2 learning. Similarly, Gass \& Selinker (2001) propose that it is regarded to be one of predictors for the success of language learning. Oxford \& Shearin (1996) believe that motivation determines the learners' active involvement in second or foreign language learning. In other words, they believe that unmotivated learners will not develop their potential ability in mastering L2. In terms of its flexibility, motivation is an area in which teachers can easily influence as it can change over time (Ellis, 1994). 
In the principle, motivation is considered to cover broad and complex spectrum when it comes to the language learning process. Gardner (1993), as cited in O'Sullivan (2008), has defined motivation as a complex thing involving three main processes namely desire to accomplish the goal, the effort associated with achieving the goal, and the reinforcement of the act of learning. Dornyei (2014) offers three paradigm of understanding the complexity of motivation answering the major questions of why people behave in that way. Motivation, based on his framework, is responsible for responding "why people decide to do something", "how long they are willing to sustain their activity", and "how hard they are going to pursue it".

Considering its ultimate influence in language learning, several theories have been proposed in order to understand motivation in a deeper way. Thus, this has created some different types of motivation proposed. Gardner and Lambert's (1959) integrative and instrumental theory was the first one of its kind. They proposed that integrative motivation is related to one's desire to communicate in his/her immediate environment and to be able to be accepted in that community. While integrative motivation deals with one's inner aspiration, instrumental motivation includes pragmatic goals e.g. getting a job in the future. Subsequently,Noels' (2001) adaptation to the former framework of motivation has emphasized two dimensions of motivation namely intrinsic and extrinsic motivation. Theformer concept deals with fulfilling one's own sake e.g. to satisfy one's curiosity. The latter, on the other hand, focuses on the process of pursuing something as a means to achieve an end e.g. achieving some rewards.

Combining some current research findings in the area of SLA and psychology, Dornyei (2005) introduced a theory of L2 motivational system and possible shelves. This framework is aimed at integrating several factors related to the learners, their tasks, and their learning environment into one system. It starts with the essential concept in psychology called possible selves. Psychologically speaking, possible shelves comprise people's future vision of what they likely want and hope. Additionally, they also consist of some tangible images and senses making it more than just a long-term plan. These possible shelves are then realized into ideal self when it comes to the discussion of L2 learning. This is because it is the realization of the concept what people want to be in the future providing some powerful motivational guide for learners.

Further, the proposed L2 motivational system by Dornyei (2005, 2009) consists of three main elements mainly derived from the possible shelves concept. They include ideal L2 self, ought-to L2 self and L2 learning experience. As previously stated, ideal L2 self deals with learners' future vision of L2 which is considered to be a specific facet. This ideal L2 self is said to be a powerful motivator in achieving the success of 12 learning since it brings the actual and ideal self closer. The next concept, ought-to self L2, deals with learners' beliefs of what they need to hold in order to avoid some possible negative results. L2 learning experience is related to their current experience of learning English in their immediate context as well as their former experiences in L2 learning.

Another important concept of motivation framework in language learning is self-determination theory proposed by Ryan and Deci (2000). They emphasize the 
importance of both intrinsic and extrinsic motivation to be taken into account by teachers and educators. Their self-determination model is a continuum showing the motivational change undergone by L2 learners. Their framework comprises three main elements namely amotivation, extrinsic motivation, and intrinsic motivation. Amotivation shows learners' lack of competence in completing something. Extrinsic motivation mainly deals with four aspects including external regulation caused by compliance and punishment, interjected regulation caused by self-control and ego-involvement, identified regulation grounded from personal importance and consciousness valuing, and integrated regulation rooted from congruence and awareness. The last of type of this kind, intrinsic motivation, is mainly rooted from interest, enjoyment, and inherent satisfaction in doing something.

Realizing the importance of motivation in fostering L2 learning, a number of studies have been conducted in this area providing different insights of motivation and its strategy in classroom context. Dornyei (1990) investigated learners' motivation in an English course in Hungary. He described that English was considered as foreign language in that country and hence provided very little opportunity for Hungarian students to be exposed to English. The results of his study revealed that instrumental motives play pivotal roles in fostering foreign language learning. The instrumental motives in Dornyei's study are referred to as instrumental motivational subsystem involving several extrinsic motives. Four dimensions of this subsystem are then identified including a general interest in foreign languages, cultures, and people, a desire to expand one's view to avoid isolation, a need of encountering new stimulus and challenges, and a desire to be accepted into certain target community.

Within another EFL context, Tran (2007) conducted a study exploring learners' motivation and identity in EFL writing classroom in Vietnam. The participants involved in her study were thirty English department students in a university in Central Vietnam. The findings of this research revealed that learners' motivation in EFL writing classroom is rooted from the combination of both extrinsic and intrinsic motivation. Extrinsic motivation refers to institutional needs, their linguistic needs, and social needs in learning EFL writing. Intrinsic motivation, on the other hand, involves learners' interest, passion, and inspiration. Another important finding of this study is that learners will perform their potential ability to write independently, creatively, and passionately if they are motivated.

Lai (2013) investigated Taiwanese university students' motivation of learning English seen from various motivational concept of L2. This study employed a survey research with a total of 267 undergraduate students of science and technology major participated. The results of this study showed that most of them study English for travel, instrumental, and integrative motives. Also, the majority of participants are motivated in learning English because of their intrinsic motivation and their ideal shelf. This research reveals that external pressure and ought-to L2 self factor of motivation do not contribute to motivate them in learning English. Though he conducted his survey with "day" and "night" school students, there was no significant difference in their motivation to learn English. 
This study is aimed at investigating non-English undergraduate students' voices in writing. It particularly scrutinizes what motivates them in learning to write in English. It portrays some factors affecting and fostering their motivation without classifying motivation into three main categorizations previously mentioned i.e. instrumental and integrative (Gardner and Lambert, 1959), intrinsic and extrinsic (Noels, 2001), and L2 motivational system of ideal-self (Dornyei, 2005, 2009). This research is conducted in integrated English class where studentslearn writing as a part of four skills to be mastered. Therefore, the students participated in this study do not take writing as an individual skill-based course.

The findings of this study are expected to provide some insights to EFL teachers and some related parties in understanding factors contributing to students' motivation in writing. Pedagogically speaking, the results of this study are also addressed to provide teachers with some ideas of developing syllabuses and materials based on the students' lived experience. Also, appropriate classroom activities and strategies can be derived from the aforementioned facts. Taking into account these findings, writing activities in EFL classroom can be directed to foster students' motivation so that they will successfully master some required macro-and micro-skills of writing.

\section{Research Methods}

The present study is aimed at investigating non-English department students' motivation in EFL writing. This study used qualitative research paradigm employing situated approach which investigates the influence of immediate learning context influences learners' disposition and the how motivation affects the learning process in a classroom setting (Shoaib \& Dornyei, 2005). Within this framework, the researcher investigated students' perspectivesof what motivates the students in EFL writing. The factors perceived by them were some reflections of their learning experience of writing in a general English class over one semester.

The participants of this study were 20 undergraduate students ( 11 females and 9 males) of Agribusiness Study Program of Faculty of Agriculture, Muhammadiyah University of Yogyakarta. At the time when this study was conducted they were all in their fourth semester. They enrolled in English IV course, a general English course offered by the Language Training Centre of UMY at the academic year of 2015/2016. The reason for choosing the participants was the feasibility to meet them twice a week offering some flexibility in conducting this research. Also, the fourthsemester students were chosen since they have had some previous learning experiences of writing since the LTC UMY has offered six series of general English course. This meant that the students' experiences could help them reflect their motivations in EFL writing deeply.

The data were collected through a questionnaire consisting six open-ended questions following Tran's framework (2007). This technique was chosen to allow students to express their attitudes and perspectives in regard to motivationin EFL writing freely. In addition, Chamot (1995) believes that this would enable each voice of the participants to be taken in to be regarded and therefore recognizes their various attitudes towards the issue. The students participating in 
this study were allowed to fill the questionnaire either in Bahasa Indonesia or English. By so doing, they were given more opportunity to reflect their own practices and experiences in learning writing. Therefore, the students would feel convenient in expressing their ideas in a more detailed way.

\section{Findings and Discussion}

The analyzed data showed that there are several main factors considered by the students to contribute as main themes concerning their voices and perspectives in learning EFL writing. They are categorized into institutional demands, linguistic needs, enthusiastic and inspiring teachers, engaging activities and tasks, interesting topics, and positive learning atmosphere.

\section{Institutional Demands}

Some students express their view that institutional demands play an important role in fostering their motivation. As previously mentioned, the studentsparticipated in this study was in their English IV course meaning that there will betwo upcoming English classes later. Understanding some skills taught in this English course will become a basis for the next courses. Since this course contributed to their GPA later on, they had to perform well in all assignment and assessment including writing. The following extract from the students' questionnaire revealed their motivational attitudes affected by institutional demands.

\section{Extract 1}

I want to succeed in this course because I will have two more classes in the next semester, so I have to be able to understand writing skills. (S5, translated by the researcher)

\section{Extract 2}

If do not pay attention to the teacher's explanation and practice my writing skills regularly, my grade will be lower than what I got last semester. (S1, translated by the researcher)

\section{Extract 3}

The English course offered by PPB (LTC UMY) is an integrated course in nature. Therefore, I have to learn and understand all skills including writing which is very important recently. (S17, translated by the researcher)

\section{Linguistic Needs}

Based on the students' voices, linguistic needs also contributed to foster their motivation in the teaching and learning process of writing. There were three main themes emerging from the students' linguistic needs of mastering EFLwriting. First, the students perceived that English has been regarded as an international language making it important to learn. With regard to the Southeast Asian context, they also added that the emergence of AEC (ASEAN Economic Community) has also fostered their motivation in learning EFL writing. Second, 
they thought that English would be important in fulfilling the expectation of their future jobs. Some students even mentioned that they were willing to be a lecturer, agricultural researcher, and multinational company employee in the future. Third, the students were also motivated in EFL writing to tackle some opportunities coming upon their graduation. One of the most frequent answers related to the future chance was the availability of scholarship to study abroad provided by Indonesian government, institution, and other countries. To be able to study abroad, they need to achieve sufficient score in writing part of the accepted English proficiency test i.e. TOEFL and IELTS. The students' voices towards this issue could be seen from the following extracts.

\section{Extract 4}

In the AEC (ASEAN Economic Community) era, English is really needed in our everyday life both for formal and informal purposes. (S8, translated by the researcher)

\section{Extract 5}

Currently, English is an international language connecting many people from different countries. Therefore, mastering English and writing skills arevery important. (S1, translated by the researcher)

\section{Extract 6}

I want to be a lecturer in the future. This requires me to be able to write in English since I have to submit papers and research reports as part of my obligation. (S4, translated by the researcher)

\section{Extract 7}

I want to continue my masters degree abroad and get a scholarship to finance my study there. To do so, I need to master writing since it isessential to make $C V$, study objective, and research proposal. It is also important to be mastered since it will increase my English proficiency(TOEFL, IELTS) score. ( $S 2$, translated by the researcher)

\section{Enthusiastic and Inspiring Teachers}

Enthusiastic and inspiring teachers were also found to foster students' motivation in EFL writing. Teachers' enthusiasm was realized in providing feedback and scaffolding the students in teaching and learning process. Feedback was perceived to help them monitor their progress in writing. Further, the students believed that by monitoring their progress they could see their own weakness so that they could be better a writer. Another indicator of teachers' enthusiasm perceived by the students was providing scaffolding. They believed that scaffolding provided them opportunity to do their writing systematically and thus improved their motivation. While teachers' enthusiasm was manifested in feedback, students also thought that teachers should incorporate sharing session on successful figure in writing. Based on their view, this could be done by telling 
them the success story of someone winning a scholarship or someone becoming a well-known writer.

\begin{abstract}
Extract 8
When I know my mistakes in writing, I will be motivated to learn and practice more. I also learn many things including grammar and other aspects through teachers' correction (feedback). (S10, translated by the researcher)
\end{abstract}

\title{
Extract 9
}

I like to get brainstorming activity at the beginning of the lesson since it helped me a lot to do writing process systematically. (S6, translated by the researcher)

\section{Extract 10}

A success story of certain people who win the scholarship or are famous writers improves my motivation in writing. When the teacher tells such story, I will do my best in writing. (S14, translated by the researcher)

\section{Engaging Activities and Tasks}

According to the students, engaging tasks and activities were one of the factors fostering their motivation in EFL writing. They preferred to be taught in an interesting way rather than simply followed what their course book suggested. Also, the students felt that teachers often used monotonous activities in practicing writing in the classroom. Based on their opinion, there were two main instructional activities considered engaging to be applied in the writing class. These included games and technology-based activities. In terms of technology- based activities, they proposed song, short movies, and videos in motivating them to write.

\section{Extract 11}

My teacher showed us a video at the beginning of the lesson. Then, he brainstormed the idea and asked us to write the explanation of the video. I think it is always interesting to learn English through video. (S3, translated by the researcher)

\section{Extract 12}

Games are exciting activities to be done in the class. This is because following the sequence of course book is sometimes boring so we need someenjoyable activities. (S2, translated by the researcher)

\section{Extract 13}

When the teacher only teach writing without games, I sometimes feel bored and thus makes me reluctant to write maximally. By playing games in the class, I will be more excited in writing English. (S8, translated by the researcher) 


\section{Interesting Topics}

Topic selection was regarded by the students to motivate them in writing English. Interesting topics, based on the students' perspectives, were those related to their daily life and those dealing with college students' life. These aforesaid topics were familiar to the students and it also provided some background knowledge to them. In addition to the two topics previously stated, the students also mentioned entertainment, sport, technology, and future aspiration providing motivation for them in EFL writing. Previous studies suggested that when students are familiar to the topic, they will find it much easier to connect their experience to their writing. The students' perspectives towards this issue can be seen in the following extracts.

\section{Extract 14}

Topics related to daily life motivate me in writing rather than any topics I haven't known before. (S8, translated by the researcher)

\section{Extract 15}

I think I will be more interested in writing if the teacher some topics which are familiar to us including college life, students' organization, and our daily life. Topics like sport, entertainment, and future job are also interesting for me. (S11, translated by the researcher)

\section{Positive Learning Atmosphere}

The students also stressed the importance of positive learning atmosphere in the teaching and learning process of writing. Positive learning atmosphere was perceived to have a closer connection to the former factor contributing to foster students' motivation i.e. engaging tasks and activities as well as interesting topics. It included relaxing and less intimidating atmosphere considered to create conducive classroom environment. The students also indicated that sharing their ideas and works to other students provided more enjoyment in EFL writing.

\section{Extract 16}

I really like relaxing classroom where the teacher does not explain the theory of writing too much but guides us to practice our writing in systematic steps. (S12, translated by the researchers)

\section{Extract 17}

My motivation in writing improves when I can share my writing to other classmates. I can then get their comments in regard to the content of my writing. (S9, translated by the researcher)

The above finding is consistent with some motivational factors perceived by EFL/ESL learners as investigated in previous studies. Tran (2007) argues that learners' motivation in writing in the Vietnamese EFL context is generated from both extrinsic and intrinsic motivation. In other words, learners' motivation in EFL writing is shaped by both their personal and contextual aspects of writing. 
She mentions that institutional needs (marks), linguistic needs, and social needs are essential in fostering learners' motivation in regard to the extrinsic motive. In addition to these factors, learners also believe that their intrinsic motivation such as interest, passion and inspiration contributes more significantly compared to those of aforesaid factors.

\section{Conclusion}

This study sought to investigate the factors influencing non-English department students' motivation in EFL writing. The data were derived from an open-ended questionnaire distributed to the fourth semester students enrolling in English IV course at LTC UMY. The findings of the present study indicated that there were six motivational factors fostering their motivation in EFL writing including institutional demands, linguistic needs, enthusiastic and inspiring teachers, engaging tasks and activities, interesting topics, and positive learning atmosphere. Taken into account these aforementioned motivational aspects in learning EFL writing, it is considered essential for teachers to scrutinize students' needs, institutional expectations, as well as their characteristics and voices. It is then suggested that teacher make a constructive collaboration in negotiating the activities, tasks, assignments, and assessment in the classroom in order to maximize and boost their motivation in EFL writing.

\section{References}

Chamot, A. (1995). The teacher's voice - action research in your classroom. ERIC/CLL News Bulletin. 18(2), 1, 5-8.

Dornyei, Z. (1990). Conceptualizing motivation in foreign language learning. Language Learning, 40, 46-78.

Dornyei, Z. (1994). Motivation and motivating in the foreign language classroom. The Modern Language Journal, 78 (3), 273- 284.

Dornyei, Z. (2005). The psychology of the language learner: Individual differences in second language acquisition. Mahwah, NJ: LawrenceErlbaum.

Dornyei, Z. (2009). The L2 Motivational Self System.In Z. Dörnyei \& E. Ushioda (Eds.), Motivation, language identity and the L2 self (pp. 9-42). Bristol: Multilingual Matters.

Dornyei, Z. (2014). Motivation in second language learning.In M. Celce-Murcia, D. M. Brinton \& M. A. Snow (Eds.), Teaching English as a second or foreign language (4th ed., pp. 518-531). Boston, MA: National Geographic Learning/Cengage Learning.

Ellis, R. (1994). The study of second language acquisition. Oxford: Oxford University Press.

Gardner, R. \& Lambert, W. (1959). Motivational variables in second language acquisition. Canadian Journal of Psychology. 13, 266-272.

Gass, S.M \& Selinker, L. (2001). Second language acquisition: An introductory course ( $2^{\text {nd }}$ ed). Mahwah, NJ: Lawrence Erlbaum Associates.

Lai, H.T.Y. (2013). The motivation of learners of English as a foreign language. International Education Studies. 6 (10), 90-101. 
Noels, K. A. (2001). New orientations in language learning motivation: Towards a model of intrinsic, extrinsic and integrative orientations, In Z. Dornyei, \& R. Schmidt (Eds.), Motivation and Second Language Acquisition. Honolulu: University of Hawai'i.

O'Sullivan, M. (2008). A study of motivation in the EFL classroom. Retrieved from http://citeseerx.ist.psu.edu/viewdoc/download?doi=10.1.1.555.4348\&rep=rep1\&type=pdf

Oxford, R.L. \& Shearin, J. (1996). Language learning motivation in a new key. In Oxford, R.L. (Ed.). Language Learning Motivation: Pathways to the New Century. Honolulu: University of Hawaii Press. 121-44.

Ryan, R. M., \& Deci, E. L. (2000). Intrinsic and Extrinsic Motivations: Classic Definition and New Directions. Contemporary Educational Psychology, 25, 54-67. http://dx.doi.org/10.1006/ceps.1999.1020

Shoaib, A., \& Dornyei, Z. (2005). Affect in life-long learning: Exploring L2 motivation as a dynamic process. In P. Benson \& D. Nunan (Eds.), Learners' stories: Difference and diversity in language learning (pp. 22-41). Cambridge: Cambridge University Press.

Tran, L.T. (2007). Learners' motivation and identity in the Vietnamese EFL writing classroom. English Teaching: Practice and Critique, 6 (1), 151-163. 